\title{
Trophic transfer of seven trace metals in a four-step marine food chain
}

\author{
Teresa Mathews ${ }^{1,2}$, Nicholas S. Fisher ${ }^{1, *}$ \\ ${ }^{1}$ Marine Sciences Research Center, Stony Brook University, Stony Brook, New York 11794-5000, USA \\ ${ }^{2}$ Institute for Radiological Protection and Nuclear Safety (IRSN), Environmental Modeling Laboratory, Cadarache, Bldg 159, \\ BP 3, 13115 St. Paul lez Durance Cedex, France
}

\begin{abstract}
There is increasing recognition of the importance of dietary pathways in determining metal body burdens in marine organisms. With a simple kinetic model that requires information about the ingestion rate of an animal and the assimilation efficiency (AE) and efflux rate constant $\left(k_{e}\right)$ of a metal following dietary exposure, it is possible to quantitatively predict the trophic transfer and biomagnification potential of a metal between trophic levels. In this study, we used radiotracers to examine the trophic transfer of 7 metals (Am, Cd, Co, Cs, Mn, Se, and Zn) in a 4-step marine food chain from phytoplankton (Isochrysis galbana) to crustacean zooplankton (Artemia salina) to juvenile sea bream (Sparus auratus) and finally to piscivorous sea bass (Dicentrarchus labrax). AEs generally were highest for Cs (63-84\%) and Se (60-77\%), and lowest for Am (<10\%) for all animals; differences in AEs for the other metals were comparatively small for all animals. There was no consistent pattern among the metal $\mathrm{k}_{\mathrm{e}} \mathrm{s}$; however, $\mathrm{k}_{\mathrm{e}} \mathrm{s}$ for any given metal tended to decrease with increasing trophic level. At each trophic step, we calculated the trophic transfer factor (TTF), defined mathematically as the ratio of metal concentration in predatory animals to metal concentration in prey organisms at steady state, and found that this ratio consistently approached or exceeded 1 for only Cs, suggesting that Cs biomagnifies at every trophic step from phytoplankton to fish. TTF values were always $<1$ for $\mathrm{Am}, \mathrm{Cd}, \mathrm{Mn}$, and $\mathrm{Co}$, suggesting that these metals are not expected to biomagnify in marine food chains. Se and Zn did not consistently display TTF values $>1$ at every trophic level, but values were close enough to unity to suggest the possibility of biomagnification under certain environmental regimes.
\end{abstract}

KEY WORDS: Trophic transfer $\cdot$ Biomagnification $\cdot$ Metals $\cdot$ Food chain

\section{INTRODUCTION}

In order to regulate public exposure to contaminants, one of the challenges faced by researchers and policy makers is to accurately describe the transfer of contaminants in the various biotic and abiotic compartments of the environment. As the consumption of metal-contaminated seafood may be the largest source of some metals (mercury, polonium) to humans, aquatic scientists have developed mathematical tools to understand and predict metal concentrations in aquatic organisms. One such tool, the biokinetic or dynamic multipathway bioaccumulation model (DYMBAM), previously described by Wang et al. (1996a) and Luoma \& Rainbow
(2005), describes the net bioaccumulation of metals in an organism as a dynamic balance between 3 mechanisms: the uptake rate from dissolved forms, the uptake rate from diet, and loss rates. This model commonly uses data generated by exploiting the properties of gamma-emitting radioisotopes with a wellestablished experimental approach to estimate metal uptake and loss kinetics under controlled laboratory conditions in simplified aquatic food chains.

Recent work highlights the importance of dietary metals in contributing to the overall metal body burden in marine organisms (Schlekat et al. 2002, Wang \& Ke 2002). Despite the importance of dietary sources of metal, little is known about bioavailability and there- 
fore the potential for bioaccumulation or biomagnification of dietary metals at different trophic levels, especially for animals at the top of the food chain. Biomagnification is defined here as the progressive bioconcentration of metals with increasing trophic level, and the potential for biomagnification can be mathematically described as the ratio of metal concentration in a predator organism to the metal concentration in its prey. If this ratio is $>1$, biomagnification is likely to occur (Reinfelder et al. 1998). This is analogous to the bioconcentration factor (BCF) used to describe bioconcentration of dissolved metals, but while BCFs have been characterized for many metals and many marine organisms, the biomagnification potential remains unknown for most predator-prey interactions and for most metals (Wang 2002).

Here, we compare the trophic transfer of 7 metals (Am, Cd, Co, Cs, Mn, Se, Zn), which differ in chemical properties and biological functions, to assess their capacities for trophic transfer in a simplified marine food chain. Included in our selection of elements were biologically essential metals (Co, Mn, and $\mathrm{Zn}$ ), nonessential metals (Am, Cs, Cd), those with redox properties (Co and $\mathrm{Mn}$ ), those with a strong affinity for sulfur $(\mathrm{Cd}, \mathrm{Zn})$ and those with a strong affinity for oxygen ligands (Am, Co, Cs, Mn). We used a simple 4-step marine food chain under controlled laboratory conditions to trace the transfer of metals from a phytoplankton base (Isochrysis galbana) ultimately to juvenile sea bass Dicentrarchus labrax. We measured the assimilation and retention of metals in animals at each trophic level and, using the biokinetic model, we were able to assess the biomagnification potential of each metal at the different trophic levels.

\section{MATERIALS AND METHODS}

Phytoplankton. Metal uptake in the prymnesiophyte Isochrysis galbana (CCMP 1323) was determined experimentally by radiotracer techniques. An axenic clonal culture of I. galbana (cell diameter $3.6 \mu \mathrm{m}$, spherical volume $24 \mathrm{\mu m}^{3}$ ) was maintained in the laboratory on a $14: 10 \mathrm{~h}$ light:dark cycle at $17 \pm 0.5^{\circ} \mathrm{C}$ in sterile-filtered $(0.2 \mu \mathrm{m})$ Mediterranean seawater amended with all f/2 nutrients (Guillard \& Ryther 1962) except $\mathrm{Cu}, \mathrm{Zn}$, and EDTA. Throughout the experiments, cultures were handled aseptically where possible, and all glassware was thoroughly washed and dried in a sterile hood under UV lamps for at least $2 \mathrm{~h}$ prior to preparation of media and inoculation. One $\mathrm{h}$ prior to the start of each experiment, 3 replicate screw-topped glass bottles filled with $500 \mathrm{ml}$ of sterile-filtered $\mathrm{f} / 2$ media (with no trace metals or EDTA) were radiolabeled with 7 metals as described below. Experimental inocula taken from an algal stock culture in late log phase growth were transferred to bottles to give an initial cell suspension of $5 \times 10^{3}$ cells ml $\mathrm{m}^{-1}$. In addition to periodically measuring cells for radioisotope content, cell growth was monitored on a daily basis using a hemacytometer. Partitioning of metal between dissolved and particulate phases over time was determined by comparing the radioisotope content associated with I. galbana cells in each experimental flask (radioisotope retained on $1 \mu \mathrm{m}$ Nuclepore filters) with the radioactivity in an equivalent volume of labeled medium (radioisotope content associated with both the aqueous phase and with cells) at each time point (Fisher et al. 1983). To determine the behavior of the added radioisotopes, including sorption to experimental materials, control flasks received the same treatment as experimental flasks, but controls contained no cells. Radioactivity associated with control filters was subtracted from radioactivity associated with experimental filters to correct for radioisotope sorption to filters. In addition, all filters were rinsed twice with unlabeled seawater to remove loosely bound metals from particle surfaces. Phytoplankton cells were allowed to grow for 1 wk to ensure they were uniformly labeled with radioisotopes before feeding to invertebrate grazers.

Invertebrate prey. Artemia salina individuals were hatched from cysts kept in aerated Mediterranean seawater at $25^{\circ} \mathrm{C}$ for $24 \mathrm{~h}$. Upon hatching, nauplii were kept at $20^{\circ} \mathrm{C}$ in aerated seawater for $2 \mathrm{~d}$ to allow sufficient reduction of yolk sacs to ensure that feeding would occur. To measure metal assimilation and loss from nauplii over time, they were presented with radiolabeled algal food as follows. I. galbana cells were filtered ( $1 \mu \mathrm{m}$ Nuclepore filter), rinsed with seawater, and resuspended in triplicate glass bottles containing $400 \mathrm{ml}$ aerated seawater, for an initial cell density of $10^{5}$ cells $\mathrm{ml}^{-1}$. Directly after resuspension of phytoplankton cells, $2 \mathrm{~d}$-old $A$. salina nauplii were added to experimental bottles at a density of 150 individuals $\mathrm{ml}^{-1}$ and fed for a period of $<1 \mathrm{~h}$. After feeding, nauplii were sieved out of feeding solutions and placed in triplicate glass bottles with clean seawater to follow metal loss over time. Directly after resuspension and periodically thereafter for a period of $2 \mathrm{~d}$, nauplii were sampled to assess radioactivity loss over time (Wang \& Fisher 1998). Depuration was plotted as percent of ingested metal retained during the $48 \mathrm{~h}$ depuration period following the pulse feeding. Assimilation efficiencies were calculated by fitting an exponential regression between 6 and $48 \mathrm{~h}$. The assimilation efficiency (AE) was estimated to be the $y$-intercept of the curve, while the efflux rate constant $\mathrm{k}_{\mathrm{e}}$ is defined as the slope of the curve (Wang \& Fisher 1999a). To assess metal trophic transfer to juvenile sea bream Sparus auratus, the above protocol was used to radiolabel 
nauplii, but instead of presenting them with a pulse of radiolabeled Isochrysis cells, nauplii were fed for $3 \mathrm{~d}$ on radio-labeled algal cells in order to produce detectable radioactivity in the fish that fed on the nauplii. In general, pulse feedings were necessary for all predator animals in this study in order to obtain the kinetic parameters $\mathrm{AE}$ and $\mathrm{k}_{\mathrm{e}}$, whereas the multiple feeding approach was used for all prey animals to obtain a more uniform labeling and to dispose of enough radiolabel to be able to follow metal depuration in the predator.

Prey fish. All fish were acclimated to laboratory conditions (water renewal rate $10 \% \mathrm{~h}^{-1}$, salinity $38 \%$, temperature $16^{\circ} \mathrm{C}$ ) for at least 1 mo prior to the start of the experiments. Juvenile Mediterranean sea bream Sparus auratus were obtained from a hatchery in Monaco as 1 mo old hatchlings; they had an average length of $2 \mathrm{~cm}$ and an average weight $<0.1 \mathrm{~g}$ at the start of experiments. Prior to experiments, sea bream were fed freshly hatched Artemia salina nauplii. To study metal depuration kinetics in $S$. auratus, A. salina nauplii that had been previously radiolabeled via their diet were introduced to a 701 closedcircuit aquarium containing 100 juvenile sea bream. The fish were allowed to feed for $1 \mathrm{~h}$, after which any uneaten nauplii were flushed from the tank. Directly after feeding and daily thereafter, triplicate samples of 5 fish each were taken at random from the tank to assess radioactive content and metal loss over time as described below. Depuration was plotted as percent of ingested metal retained during the $14 \mathrm{~d}$ depuration period following the pulse feeding. AEs were calculated by fitting an exponential regression between 1 and $14 \mathrm{~d}$. AE was estimated to be the $y$-intercept of the curve, while the efflux rate constant $\mathrm{k}_{\mathrm{e}}$ is defined as the slope of the curve (Wang \& Fisher 1999a).

To assess metal trophic transfer from Sparus auratus to juvenile sea bass Dicentrarchus labrax, we used the same radiolabeling protocol for $S$. auratus, but instead of presenting them with a pulse of radiolabeled nauplii, individuals were fed for $7 \mathrm{~d}$ on radiolabeled nauplii in order to produce sufficient radioactivity for detection in D. labrax.

Predator fish. Individuals of the Mediterranean sea bass Dicentrarchus labrax (8.1 $\pm 4.4 \mathrm{~g}$ mean wet weight) were obtained from a hatchery in Monaco and acclimated to experimental conditions (water renewal rate $10 \% \mathrm{~h}^{-1}$, salinity $38 \%$, temperature $16^{\circ} \mathrm{C}$ ) in a well aerated $120 \mathrm{l}$ aquarium for at least $3 \mathrm{wk}$ prior to experiments, during which time they were fed on a mixed diet of frozen shrimp, mussels, squid, and fish. For the experiments, 36 juvenile Sparus auratus individuals previously radiolabeled through their diet (and with their guts cleared from the last radiolabeled meal) were introduced to the D. labrax aquarium and the sea bass were allowed to feed for $2 \mathrm{~h}$ in the dark. After pulse-feeding on live radiolabeled prey fish, radioactivity associated with predator fish was measured on a daily basis for the first week, and then every other day for an additional $3 \mathrm{wk}$. This was sufficient time to purge sea bass guts of unassimilated labeled food (egested in feces, representing rapid loss from the fish) and to follow the more gradual loss of assimilated metal over time (slower loss from the fish). During the depuration period, the predator fish were kept in flowing seawater (water renewal rate $10 \% \mathrm{~d}^{-1}$ ) and fed daily on their mixed diet of non-radioactive shrimp, mussels, squid, and fish, and the loss of radioactivity from the the animals was measured periodically. Data were analyzed to determine $\mathrm{AE}$ and $\mathrm{k}_{\mathrm{es}}$ for each radioisotope as described above for $S$. auratus. After 1 and 3 wk of depuration, 6 fish were selected at random and dissected into 5 compartments (gill, viscera, muscle, skeleton, and skin), and radioactivity associated with each compartment was measured to determine whether retention of metals was uniform within the animal or varied significantly between different tissues.

Radioisotopes and analyses. We used high specific activity radioisotopes obtained from Amersham UK $\left({ }^{60} \mathrm{Co},{ }^{134} \mathrm{Cs},{ }^{109} \mathrm{Cd},{ }^{241} \mathrm{Am}\right)$, Polatom $\left({ }^{75} \mathrm{Se}\right)$ and Isotope Products $\left({ }^{54} \mathrm{Mn},{ }^{65} \mathrm{Zn}\right)$. Isotopes were dissolved in $0.1 \mathrm{~N}$ $\mathrm{HCl}\left(\mathrm{Cd}\right.$ as $\mathrm{CdCl}_{2}, \mathrm{Mn}$ as $\mathrm{MnCl}_{2}$, Co as $\mathrm{CoCl}_{2}$ ), $0.5 \mathrm{~N}$ $\mathrm{HCl}\left(\mathrm{Zn}\right.$ as $\left.\mathrm{ZnCl}_{2}\right), 3 \mathrm{~N} \mathrm{HNO}_{3}\left(\mathrm{Am}\right.$ as $\left.\mathrm{Am}\left(\mathrm{NO}_{3}\right)_{3}\right)$, or in water ( $\mathrm{Cs}$ as $\mathrm{CsCl}$, Se as $\mathrm{Na}_{2} \mathrm{SeO}_{3}$ ). Typically, $\mu$ quantities of these solutions were added to experimental phytoplankton bottles to yield the following activities: $0.5 \mathrm{~Bq} \mathrm{ml}{ }^{-1}$ for ${ }^{241} \mathrm{Am}, 1 \mathrm{~Bq} \mathrm{ml}^{-1}$ for each of ${ }^{60} \mathrm{Co}^{,}{ }^{54} \mathrm{Mn}$, ${ }^{65} \mathrm{Zn},{ }^{75} \mathrm{Se}, 2 \mathrm{~Bq} \mathrm{ml}{ }^{-1}$ for ${ }^{134} \mathrm{Cs}$, and $5 \mathrm{~Bq} \mathrm{ml}^{-1}$ for ${ }^{109} \mathrm{Cd}$, corresponding to the following concentrations: $4.6 \mathrm{fM}$ ${ }^{241} \mathrm{Am}, 0.4 \mathrm{pM}{ }^{60} \mathrm{Co}, 83.4 \mathrm{pM}{ }^{54} \mathrm{Mn}, 10.1 \mathrm{pM}{ }^{65} \mathrm{Zn}$, $3.5 \mathrm{pM}{ }^{75} \mathrm{Se}, 1.4 \mathrm{nM}{ }^{134} \mathrm{Cs}$, and $3.4 \mathrm{pM}{ }^{109} \mathrm{Cd}$. These additions were below ambient surface seawater concentrations for all metals except Am. In all cases, $\mathrm{pH}$ was unaffected.

Radioactivity in all samples was determined using a high resolution $\gamma$ spectrometry system consisting of four coaxial germanium ( $\mathrm{N}$ - or P-type) detectors (EGNC 33-195-R, Intertechnique) connected to a multi-channel analyzer (Interwinner6, Intertechnique). Radioactivity of the samples was determined by comparison with the radioactivity in standards of appropriate geometry and corrected for background and decay. To minimize errors in gamma counting due to sample geometry, movement of fish within counting chambers was limited by placing a minimal amount of water in the counting chambers, and in the case of Dicentrarchus labrax, by constraint with a semi-circular tube. Gamma emissions of $\mathrm{Am}, \mathrm{Co}, \mathrm{Cs}, \mathrm{Cd}, \mathrm{Mn}, \mathrm{Se}$, and $\mathrm{Zn}$ 
were assayed at $60,1173,605,88,835,265$, and 1116 $\mathrm{keV}$, respectively. Counting times were adjusted to yield counting errors $<5 \%$ where possible, or to a maximum of 15 min for live fish.

Modeling trophic transfer of metals. The bioaccumulation of metals in aquatic organisms can be described as a balance between metal uptake and loss rates. The bioaccumulation model that we applied has been used extensively for marine invertebrates, but more recently has also been applied to fish (Zhao et al. 2001, Baines et al. 2002, Pickhardt et al. 2006). At steady state, tissue metal concentration derived from dietary exposure is described by the following equation:

$$
\mathrm{C}_{\mathrm{ss}}=\left(\mathrm{AE} \times \mathrm{IR} \times \mathrm{C}_{\mathrm{f}}\right) /\left(\mathrm{k}_{\mathrm{e}}+g\right)
$$

where $C_{s s}$ is the steady state metal concentration in an organism, AE is the assimilation efficiency of the ingested metal in the animal, IR is the weight-specific ingestion rate, $C_{f}$ is the metal concentration in the food, $k_{\mathrm{e}}$ is the efflux rate constant of the metal out of the animal, and $g$ is the growth rate constant of the animal. Rearranging this equation to express the ratio of metal concentration in an organism in relation to the concentration in its prey allows assessment of the potential of a metal to biomagnify at different sequential steps in the food chain. This ratio is called the trophic transfer factor (TTF) and can be calculated as follows (Reinfelder et al. 1998, Wang \& Fisher 1999b):

$$
\mathrm{TTF}=\mathrm{C}_{\mathrm{ss}} / \mathrm{C}_{\mathrm{f}}=(\mathrm{AE} \times \mathrm{IR}) /\left(\mathrm{k}_{\mathrm{e}}+g\right)
$$

A TTF value $>1$ indicates a possibility of biomagnification and values $<1$ suggest that biomagnification is unlikely.

For the TTF calculations, we considered a range of assimilation efficiencies and ingestion rates for all organisms. Experiments were performed to determine weight-specific IR of nauplii at different phytoplankton cell densities using the equation:

$$
\mathrm{IR}=\mathrm{W}_{\mathrm{pp}} \times \mathrm{V} \times\left(\mathrm{C}_{0}-\mathrm{C}_{\mathrm{t}}\right) /\left(\mathrm{N} \times \mathrm{t} \times \mathrm{W}_{\mathrm{n}}\right)
$$

where $\mathrm{W}_{\mathrm{pp}}$ is the dry weight of the phytoplankton cell (g), V is the volume of seawater in which the phytoplankton cells are suspended $(\mathrm{ml}), \mathrm{C}_{0}$ and $\mathrm{C}_{\mathrm{t}}$ are the algal cell densities before and after feeding, respectively (cells ml-1), $\mathrm{N}$ is the number of Artemia nauplii used in the experiment, $\mathrm{W}_{\mathrm{n}}$ is the weight of each nauplius (g), and $\mathrm{t}$ is the feeding time (d). Measured ingestion rates were used to calculate TTFs for Artemia nauplii and ranged from 0.1 to $0.5 \mathrm{~g}$ (g bodyweight $\left.{ }^{-1}\right) \mathrm{d}^{-1}$, depending on phytoplankton cell density. We used an IR range of 0.01 to $0.1 \mathrm{~g}$ (g bodyweight ${ }^{-1}$ ) $\mathrm{d}^{-1}$ for Sparus auratus and Dicentrarchus labrax based on prior studies done with similarly sized fish (Pauly 1989, GarnierLaplace et al. 2000). Because efflux rate constants have been shown not to differ significantly with temperature (Baines et al. 2005) or with various other environmental conditions (Fisher et al. 1996), mean values were used for TTF calculations.

\section{RESULTS}

Growth and metal accumulation over time in Isochrysis galbana expressed as percent of total radioactivity associated with cells is shown in Fig. 1. Concentration factors at the end of the uptake period were calculated on a volume/volume basis (VCF) as moles metal per volume of cell divided by moles metal per equivalent volume of ambient water (dissolved), as described elsewhere (Fisher et al. 1983). In general, particulate metal increased over time, closely following the increase in cell numbers (and therefore particulate surfaces), yielding a steady-state relationship between metal content associated with cells relative to

Table 1. Volume concentration factors (VCF: concentration of metal per volume of cell, divided by the dissolved metal concentration per equivalent volume of ambient water) in Isochrysis galbana $(\mathrm{n}=3)$ and assimilation efficiencies (AE) and efflux rate con-

\begin{tabular}{|c|c|c|c|c|c|c|c|}
\hline \multirow[t]{2}{*}{ Metal } & \multirow{2}{*}{$\begin{array}{c}\text { Isochrysis galbana } \\
\text { VCF } \\
\left(\times 10^{4}\right)\end{array}$} & \multicolumn{2}{|c|}{ Artemia salina nauplii } & \multicolumn{2}{|c|}{ Juvenile Sparus auratus } & \multicolumn{2}{|c|}{ Juvenile Dicentrarchus labrax } \\
\hline & & $\begin{array}{l}\mathrm{AE} \\
(\%)\end{array}$ & $\begin{array}{c}\mathrm{k}_{\mathrm{e}} \\
\left(\mathrm{d}^{-1}\right)\end{array}$ & $\begin{array}{l}\mathrm{AE} \\
(\%)\end{array}$ & $\begin{array}{l}\mathrm{k}_{\mathrm{e}} \\
\left(\mathrm{d}^{-1}\right)\end{array}$ & $\begin{array}{l}\mathrm{AE} \\
(\%)\end{array}$ & $\begin{array}{c}\mathrm{k}_{\mathrm{e}} \\
\left(\mathrm{d}^{-1}\right)\end{array}$ \\
\hline Am & 22.36 & $9.9 \pm 1.6$ & 0.26 & $4.06 \pm 3.0$ & 0.04 & $6.06 \pm 2.4$ & $0.11 \pm 0.16$ \\
\hline $\mathrm{Cd}$ & 9.38 & $29.9 \pm 1.6$ & 0.54 & $21.0 \pm 15.0$ & 0.14 & $22.9 \pm 8.5$ & $0.07 \pm 0.05$ \\
\hline Co & 1.56 & $25.7 \pm 0.6$ & 0.29 & $11.5 \pm 4.1$ & 0.04 & $20.7 \pm 7.5$ & $0.05 \pm 0.02$ \\
\hline $\mathrm{Cs}$ & 0.01 & $62.7 \pm 3.0$ & 0.52 & $84.4 \pm 4.1$ & 0.05 & $78.9 \pm 3.2$ & $0.03 \pm 0.02$ \\
\hline $\mathrm{Mn}$ & 7.28 & $15.8 \pm 6.8$ & 0.55 & $18.0 \pm 6.9$ & 0.10 & $33.2 \pm 8.8$ & $0.09 \pm 0.13$ \\
\hline $\mathrm{Se}$ & 11.20 & $60.4 \pm 5.8$ & 0.60 & $76.6 \pm 15.8$ & 0.13 & $64.3 \pm 11.9$ & $0.06 \pm 0.03$ \\
\hline $\mathrm{Zn}$ & 19.45 & $27.6 \pm 3.1$ & 0.61 & $14.4 \pm 10.5$ & 0.04 & $38.1 \pm 10.0$ & $0.02 \pm 0.01$ \\
\hline
\end{tabular}
stants $\left(\mathrm{k}_{\mathrm{e}}\right)$ of $\mathrm{Am}, \mathrm{Cd}, \mathrm{Co}, \mathrm{Cs}, \mathrm{Mn}, \mathrm{Se}$, and $\mathrm{Zn}$ in Artemia salina nauplii $(\mathrm{n}=3)$ fed on I. galbana, juvenile Sparus auratus $(\mathrm{n}=3)$ fed on A. salina nauplii, and juvenile Dicentrarchus labrax $(\mathrm{n}=12)$ fed juvenile $S$. auratus. Means $\pm \mathrm{SD}$ 


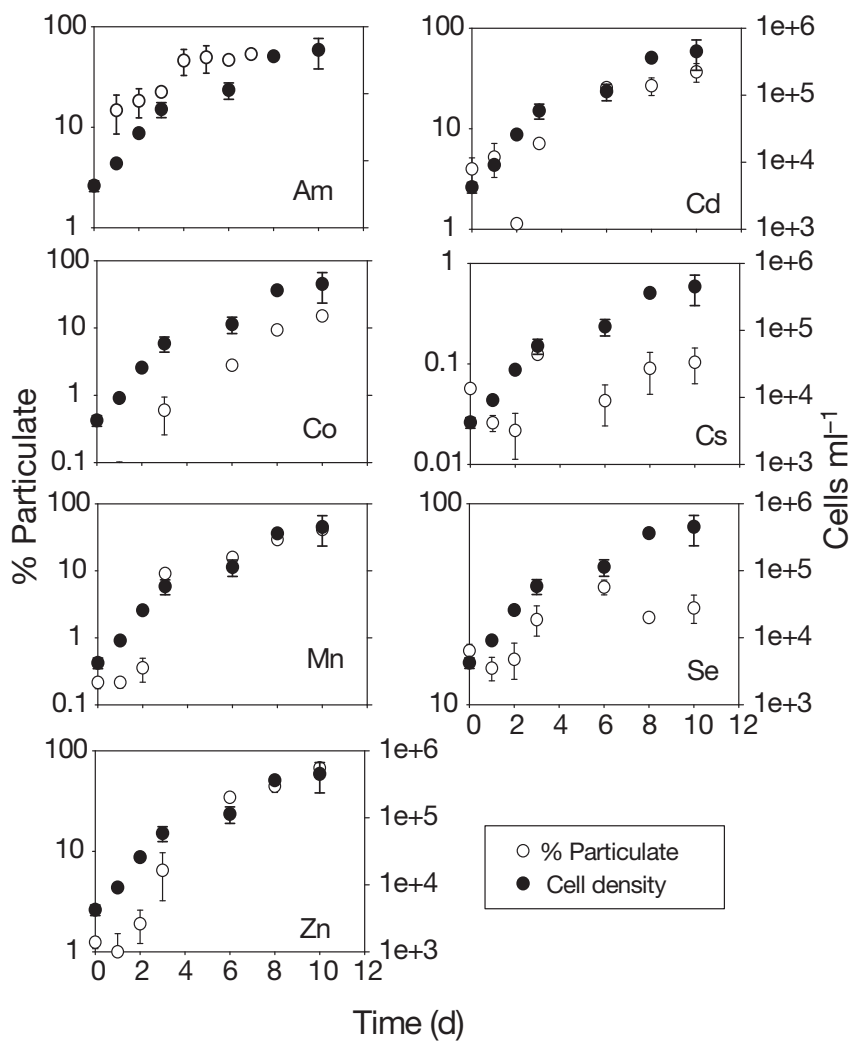

Fig. 1. Isochrysis galbana. Growth (no. cells $\mathrm{ml}^{-1}$, right axes) and metal uptake over time (\% particulate, left axes). Means $\pm \mathrm{SE}, \mathrm{n}=3$

the ambient water. At steady-state, I. galbana cells removed $67 \%$ of dissolved $\mathrm{Zn}$ from solution, about $50 \%$ of $\mathrm{Am}, 40 \%$ of $\mathrm{Mn}$ and $\mathrm{Cd}, 30 \%$ of $\mathrm{Se}, 15 \%$ of $\mathrm{Co}$, and $<1 \%$ of dissolved Cs. VCFs in I. galbana for all metals are shown in Table 1 ; they ranged from 130 for Cs to approximately $2 \times 10^{5}$ for Am and Zn.

Preliminary experiments showed that freshly hatched Artemia nauplii did not feed for the first 24-48 h after hatching and, accordingly, feeding experiments used 48 h-old nauplii. Periodic cell counts using a hemacytometer confirmed that nauplii ingested the radiolabeled cells during the exposure period. Fig. 2 shows the depuration curves of the metals from the nauplii after being removed from radiolabeled feeding suspensions. In general, metal loss was rapid during the first $6 \mathrm{~h}$, corresponding to gut clearance, but stabilized after about 12 h. Efflux rate constants are shown in Table 1. Mean assimilation efficiencies calculated for nauplii feeding on Isochrysis galbana are also shown in Table 1 and ranged from about $10 \%$ for Am to about $60 \%$ for Cs and Se. Fig. 3 shows the calculated TTFs of each metal for Artemia feeding on phytoplankton. Artemia TTFs approached unity for Cs and Se at the higher range of ingestion rates, but were $<1$ for all other metals.

The retention of metals in juvenile Sparus auratus after feeding on radiolabeled Artemia salina followed a 2-compartment loss (Fig. 4), with an initial rapid loss period, corresponding to gut clearance in the fish, followed by a slower loss representing physiological turnover of the metals. Calculated assimilation efficiencies and efflux rate constants in these fish are given in Table 1. As for Artemia, assimilation efficiencies in $S$. auratus were highest for Cs $(84 \pm 4 \%)$ and Se $(77 \pm 15 \%)$, and AEs were $\leq 20 \%$ for all other metals. Fig. 5 shows the TTFs for each metal in $S$. auratus feeding on Artemia. TTF values exceeded 1 only for Cs at the high end of the ingestion rate considered, and approached 1 for Se and Zn.

After feeding on a pulse of radiolabeled prey fish, loss patterns of metals in Dicentrarchus labrax (Fig. 6) were similar to those of Sparus auratus. Calculated values of $\mathrm{AE}$ and $\mathrm{k}_{\mathrm{e}}$ for D. labrax are shown in Table 1. Mean AEs $( \pm \mathrm{SD})$ were highest for Cs $(79 \pm 3 \%)$ and Se $(64 \pm 12 \%)$, and lowest for Am $(6 \pm 2 \%)$. Mean efflux rate constants ranged from $0.02 \mathrm{~d}^{-1}$ for $\mathrm{Zn}$ to $0.11 \mathrm{~d}^{-1}$ for Am (Table 1).

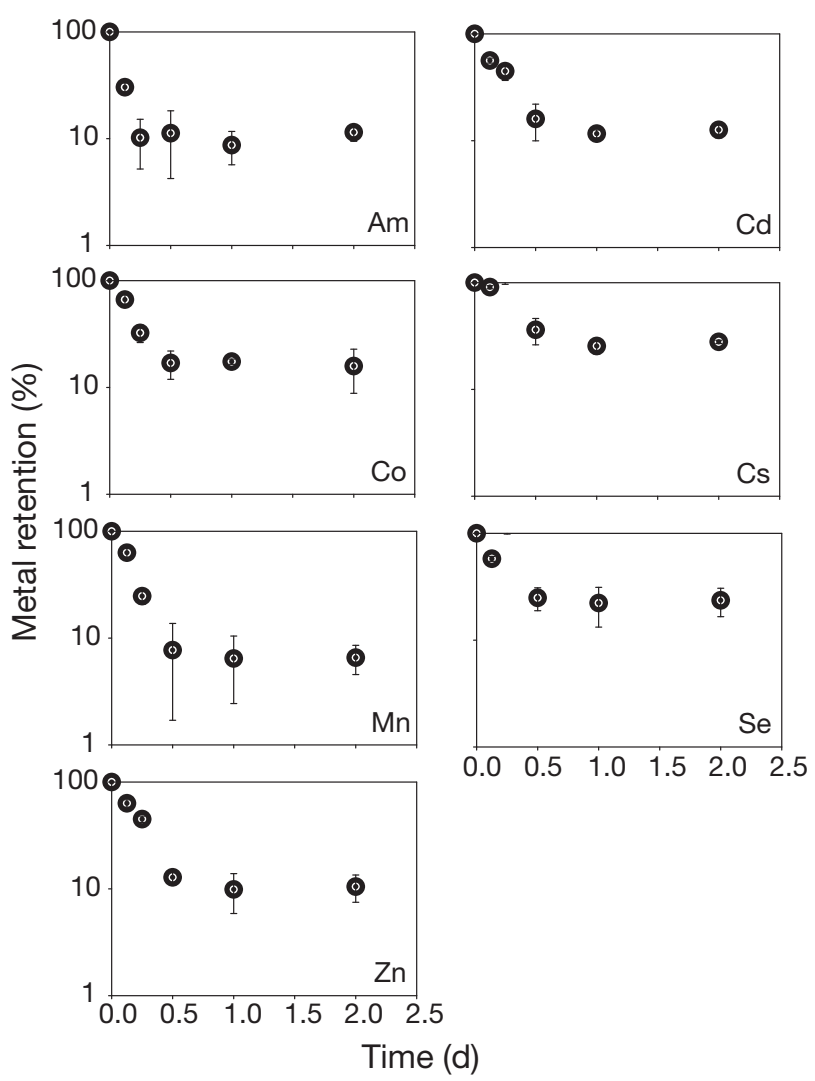

Fig. 2. Artemia salina. Metal retention in nauplii after pulsefeeding with Isochrysis galbana. Retention is expressed as $\%$ of initial radioactivity in $A$. salina. Means $\pm \mathrm{SE}, \mathrm{n}=3$, 150 individuals per replicate 

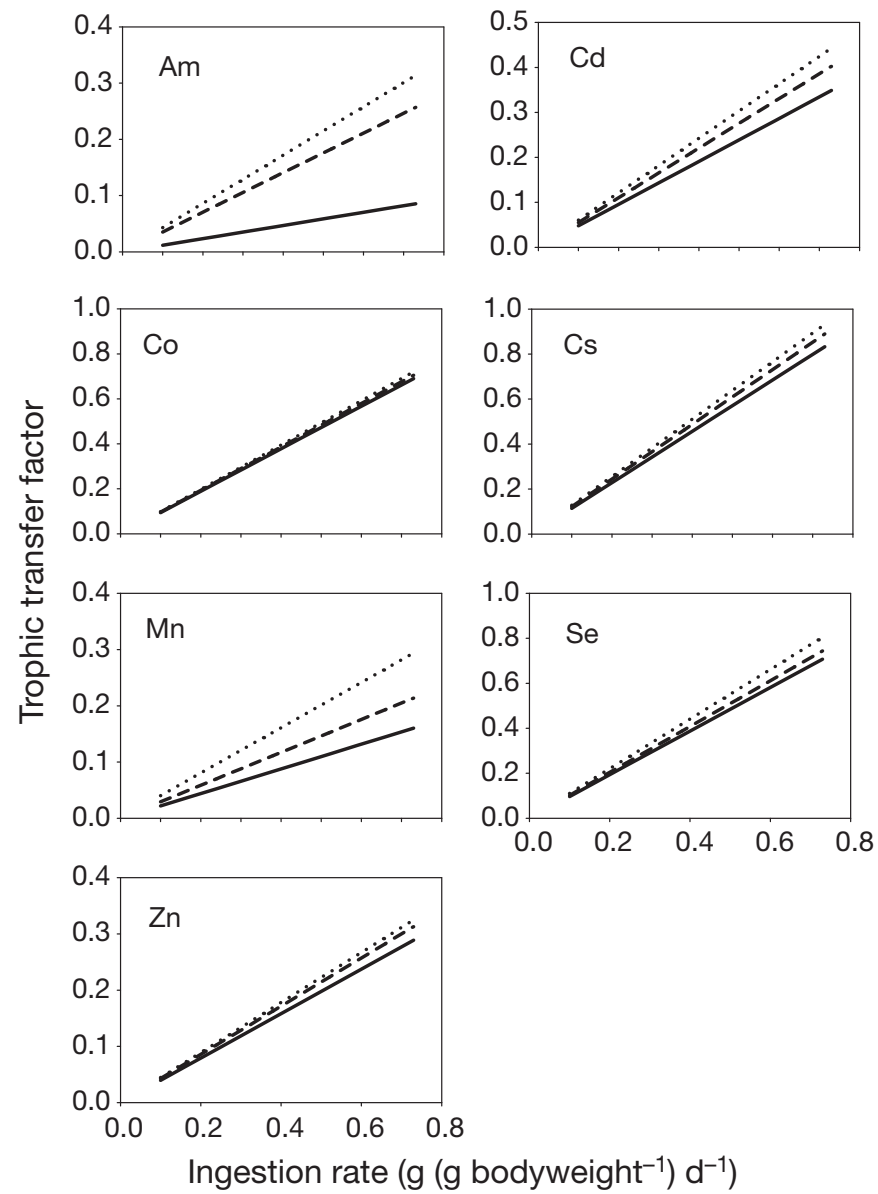

Fig. 3. Artemia salina. Model-predicted trophic transfer factor (TTF) values as a function of ingestion rate (IR) for nauplii feeding on Isochrsysis galbana using kinetic parameters shown in Table 1. Calculated TTF values use mean efflux rate konstant $\left(\mathrm{k}_{\mathrm{e}}\right)$ values and lowest (-), highest (....), and mean $(--)$ assimilation efficiency (AE) values determined for each metal

Model-predicted TTFs were plotted against IR for the range of AEs observed in Dicentrarchus labrax (Fig. 7). Our model calculations indicate that TTF values were consistently $<1$ for the range of ingestion rates considered and for the range of AEs observed for $\mathrm{Am}, \mathrm{Cd}, \mathrm{Mn}$, and $\mathrm{Se}$, suggesting that these metals would not biomagnify at this trophic level. TTF values for $\mathrm{Cs}$ and Co were $>1$ for the highest values of $\mathrm{AE}$ observed and at the highest ingestion rates considered, while Zn TTF values were $>1$ for both the mean AE and the highest $\mathrm{AE}$ observed at the high end of the ingestion rates considered.

Dissections after 1 and 3 wk of depuration suggested a redistribution of metals from the gut to other compartments of the fish. Tissue distributions shown in Fig. 8 indicate that, after 1 wk of depuration, a considerable amount of metal remained in the viscera (stom- ach and intestines) of Dicentrarchus labrax, ranging from $16 \%$ of the total remaining Am to $36 \%$ of the total remaining $\mathrm{Cd}$ in this compartment. A large fraction of all metals was also found in the gills, with percentages in this compartment ranging, after $1 \mathrm{wk}$ of depuration, from $20 \%$ for $\mathrm{Co}, \mathrm{Mn}$ and $\mathrm{Cs}$, up to $40 \%$ for $\mathrm{Am}$. Expressed on a tissue weight-normalized basis (Fig. 8), muscle tissue was least enriched after $1 \mathrm{wk}$, with percentages $<5 \%$ for all metals except Cs. Expressed as percentage of total metal body burden (not shown), metals were generally mostly found in the skin and viscera except for Cs, which was highest in muscle tissue. In general, the relative fraction of all metals in the viscera and gills decreased from 1 to 3 wk of depuration, while increases occurred in different tissues for different metals. For example, the relative fraction of Am, $\mathrm{Cd}, \mathrm{Co}, \mathrm{Se}$, and $\mathrm{Zn}$ in the liver increased substantially, while the relative fraction of Cs increased significantly in the muscle and skeleton. At the end of the 3-wk depuration period, Cs was the only metal with highest proportional representation in the muscle tissue of D. labrax.

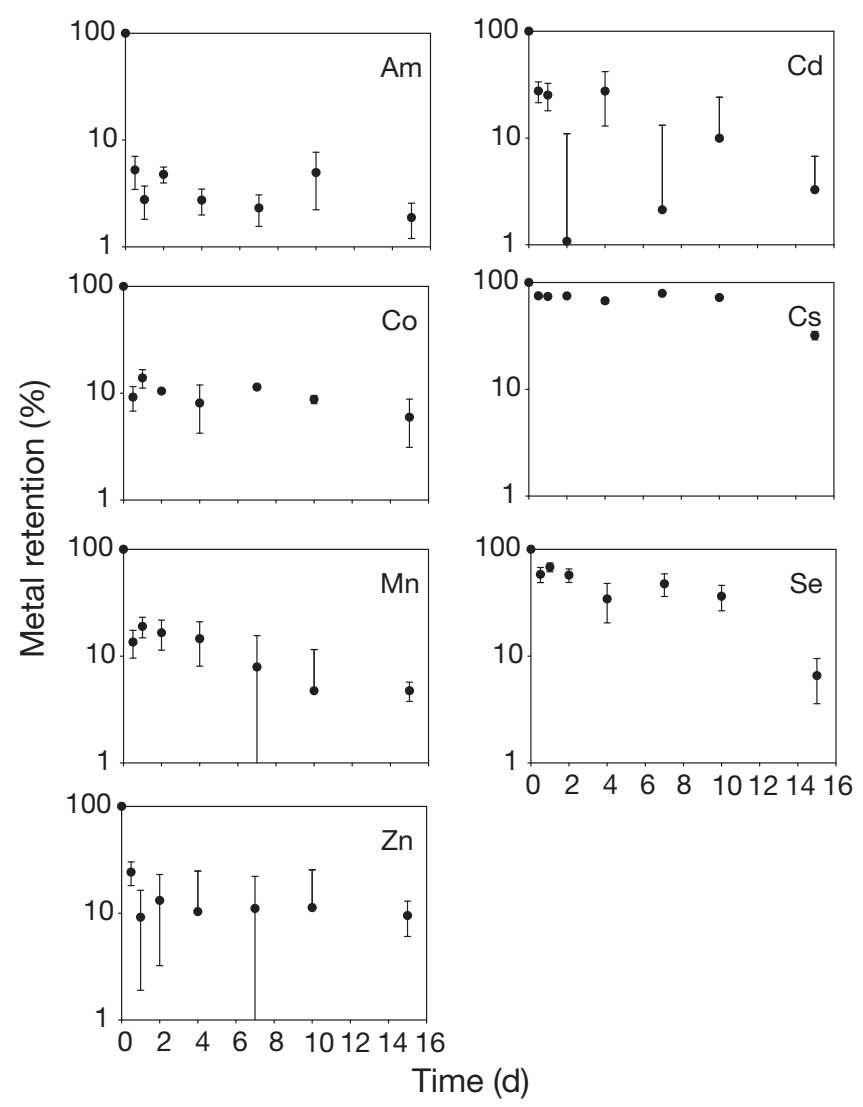

Fig. 4. Sparus auratus. Metal retention after pulse-feeding on Artemia salina. Retention is expressed as percent of initial metal body burden. Means $\pm \mathrm{SE}, \mathrm{n}=3,5$ individuals per replicate 

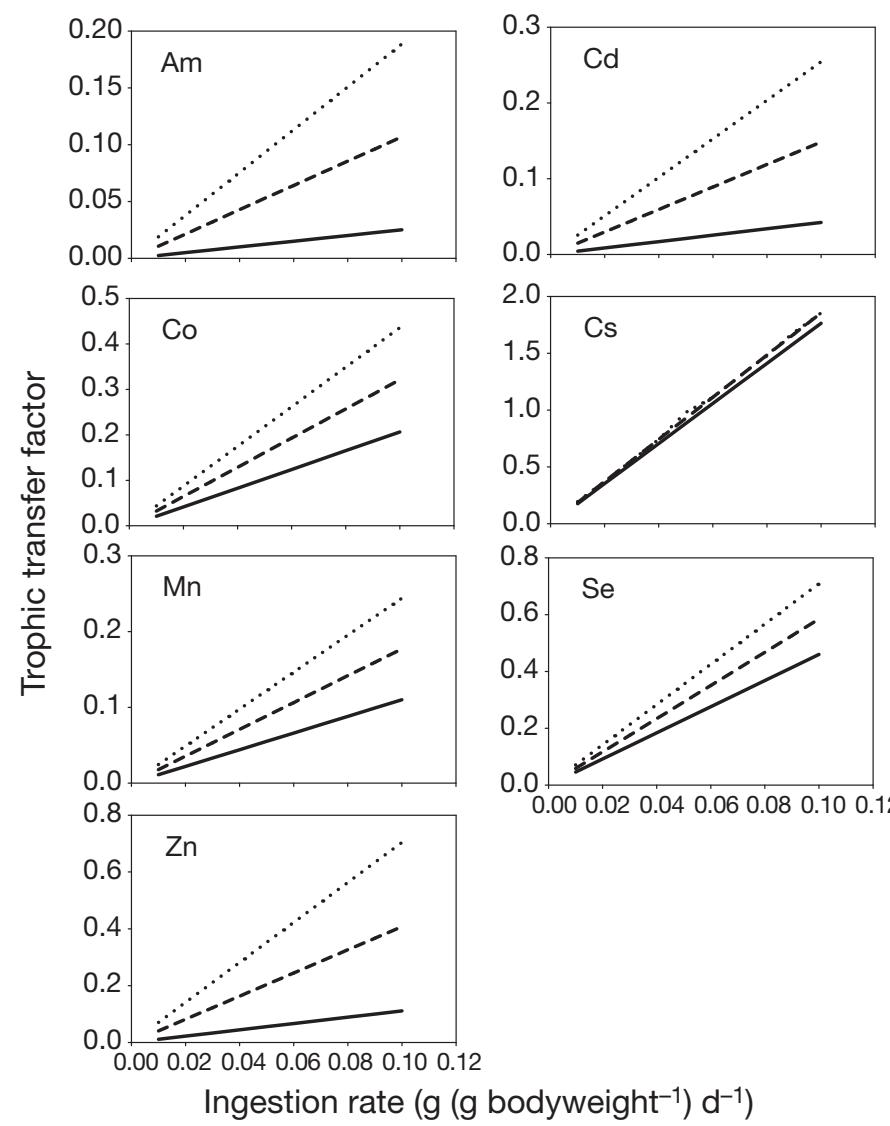

Fig. 5. Sparus auratus. Model-predicted trophic transfer factor (TTF) values as a function of ingestion rate (IR) for fish feeding on Artemia salina using kinetic parameters shown in Table 1. Calculated TTF values use mean efflux rate constant $\left(\mathrm{k}_{\mathrm{e}}\right)$ values and lowest (-), highest $(\cdots \cdot)$, and mean (---) assimilation efficiency (AE) values determined for each metal

\section{DISCUSSION}

The routes of exposure of an aquatic animal to metals can influence tissue distributions and the fates of metals that are ingested (Fisher et al. 1996, Hook \& Fisher 2001, Pickhardt et al. 2006), potentially influencing metal bioavailability to predators. Meyer et al. (2005) reviewed many previous investigations on aquatic animals that evaluated the accumulation and toxic effects of metals in the diet. Many earlier studies relied on artificial feeds or dietary components in which metals were added by such methods as injection into prey items or into ground fish meal, or through direct exposure to metals in the aqueous phase for relatively short periods of time. Further, some studies, particularly those focusing on toxic effects, used metal concentrations far in excess of those occurring in most natural waters. In contrast to this approach, our study of metal trophic transfer to piscivorous fish used living prey exposed over days to environmentally realistic levels of metals in the diet. This approach presumably allowed the metals to associate with tissues in prey organisms in an environmentally relevant way and more closely mimic natural systems; therefore, the findings may be extrapolated as an aid in understanding processes in natural waters.

Because the biggest bioconcentration step for many metals is at the base of the aquatic food chain and metal concentration factors generally decrease from phytoplankton to fish (IAEA 2004), the accumulation of metals in phytoplankton may be a key determinant of metal concentrations in marine animals in phytoplankton-based food chains. While this appears to hold true for most metals, Cs showed minimal accumulation from the dissolved phase into phytoplankton cells, with only $0.1 \%$ of the total Cs added being associated with cells after $1 \mathrm{wk}$ of exposure (Fig. 1). Our observed VCF of 130 is comparable to reported values, which range from 100 to 1000, depending on phytoplankton species (IAEA 2004). The low VCF is likely attributable to the high potassium:cesium ratio in seawater $\left(5 \times 10^{6}\right)$, as Cs is an analog for $\mathrm{K}$ and may enter cells via $\mathrm{K}$-uptake

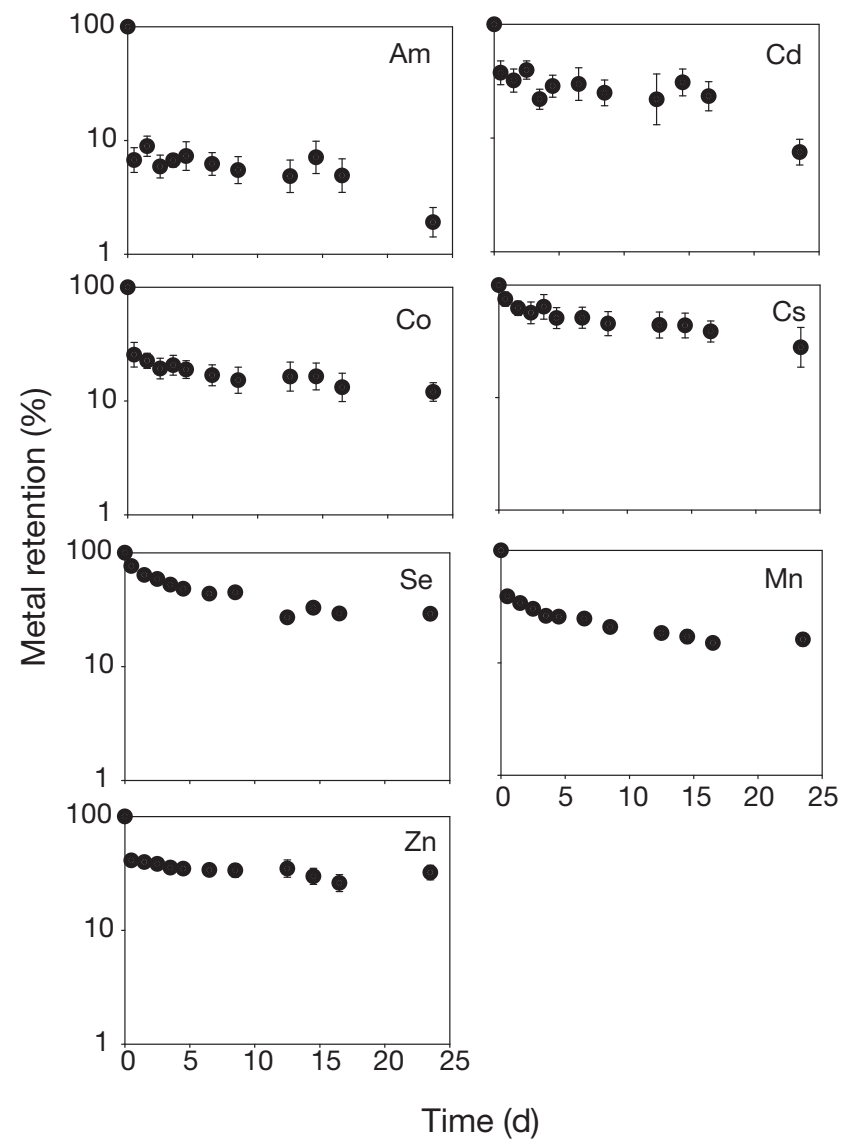

Fig. 6. Dicentrarchus labrax. Metal retention after pulse feeding on Sparus auratus. Retention is expressed as \% initial metal body burden. Means $\pm \mathrm{SE}, \mathrm{n}=12$ 

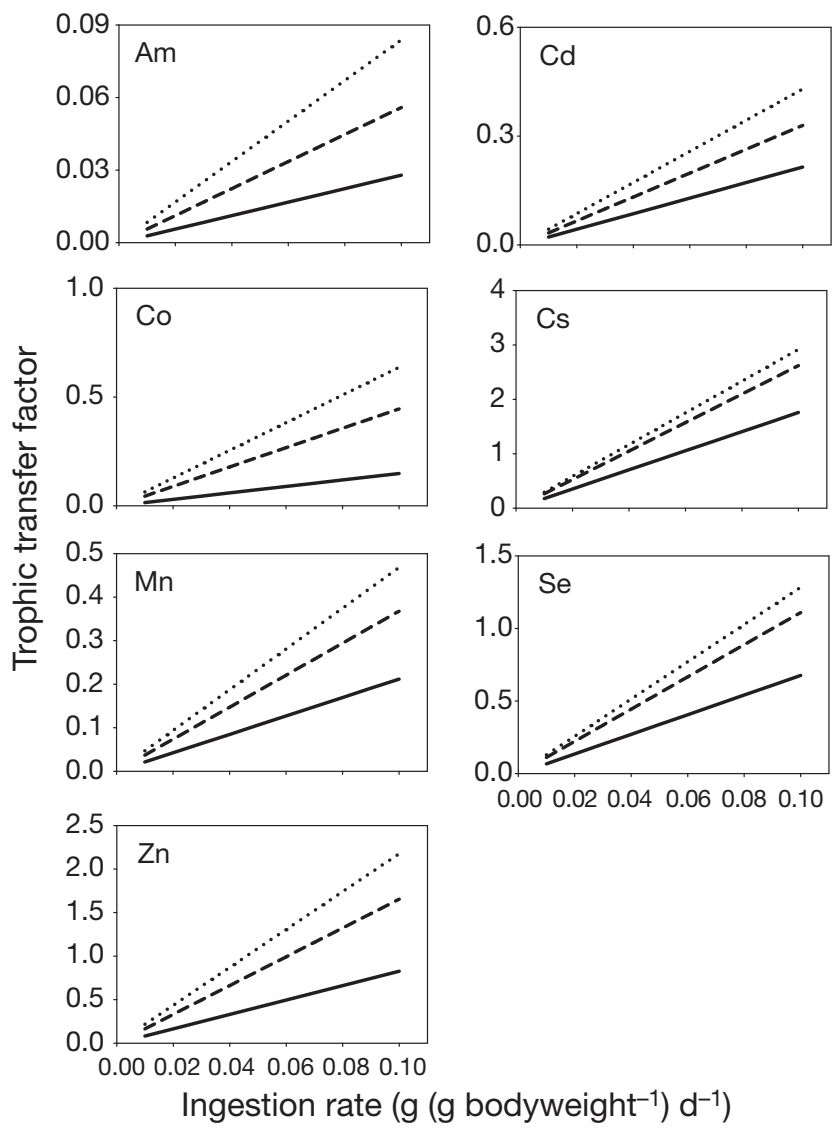

Fig. 7. Dicentrarchus labrax. Model-predicted trophic transfer factor (TTF) values as a function of ingestion rate (IR) for fish feeding on Sparus auratus using kinetic parameters shown in Table 1. Calculated TTF values use mean efflux rate konstant $\left(\mathrm{k}_{\mathrm{e}}\right)$ values and lowest (-), highest $(\cdots \cdot \cdot)$, and mean (---) assimilation efficiency (AE) values determined for each metal

channels. Consistent with this reasoning, Cs concentration factors in phytoplankton are significantly higher in freshwater than in seawater (Adam \& Garnier-Laplace 2003).

In our experiments, the 2 metals that associated most with Isochrysis galbana cells ( $>50 \%$ of total added metal) were $\mathrm{Zn}$ and Am, resulting in the highest VCFs. These 2 metals differ in that $\mathrm{Zn}$ is used in the structural scaffolding of many proteins and has transporters that bring it into the cell, while Am has no biological function and generally remains sorbed to the exterior of cells (Reinfelder \& Fisher 1991). Am is a trivalent cation with a considerably larger ionic radius than the other metals considered here, and probably cannot be 'mistaken' for other essential metals by cellular uptake pathways. By contrast, Cd, a non-essential metal, has an ionic radius similar to those of other divalent cations we examined and may also penetrate into algal cells through the uptake channels used for metals such as
$\mathrm{Zn}$, an essential element. Cd does penetrate into algal cytoplasm (Reinfelder \& Fisher 1991) and replaces Zn in carbonic anhydrase of algal cells when internal $\mathrm{Zn}$ levels are low (Morel et al. 1994). Se, Mn, and Co are all essential metals and of the 3, Se had the highest VCF and the greatest potential to build up in marine food chains.

The partitioning of metals between the dissolved phase and the cells, and the partitioning of metals within phytoplankton cells, can influence the magnitude of trophic transfer to herbivores and hence the likelihood of subsequent passage up the food chain (Fisher \& Reinfelder 1995). We did not measure the partitioning of metals within cells, but our assimilation efficiency estimates for Artemia nauplii are comparable with reported values for these metals in copepods and bivalve larvae feeding on diatoms and Isochrysis galbana (Reinfelder \& Fisher 1994).

While Cs had the lowest algal VCF of the 7 metals in this study, it had the highest AE in Artemia nauplii feeding on Isochrysis galbana (Fig. 2, Table 1). Heldal

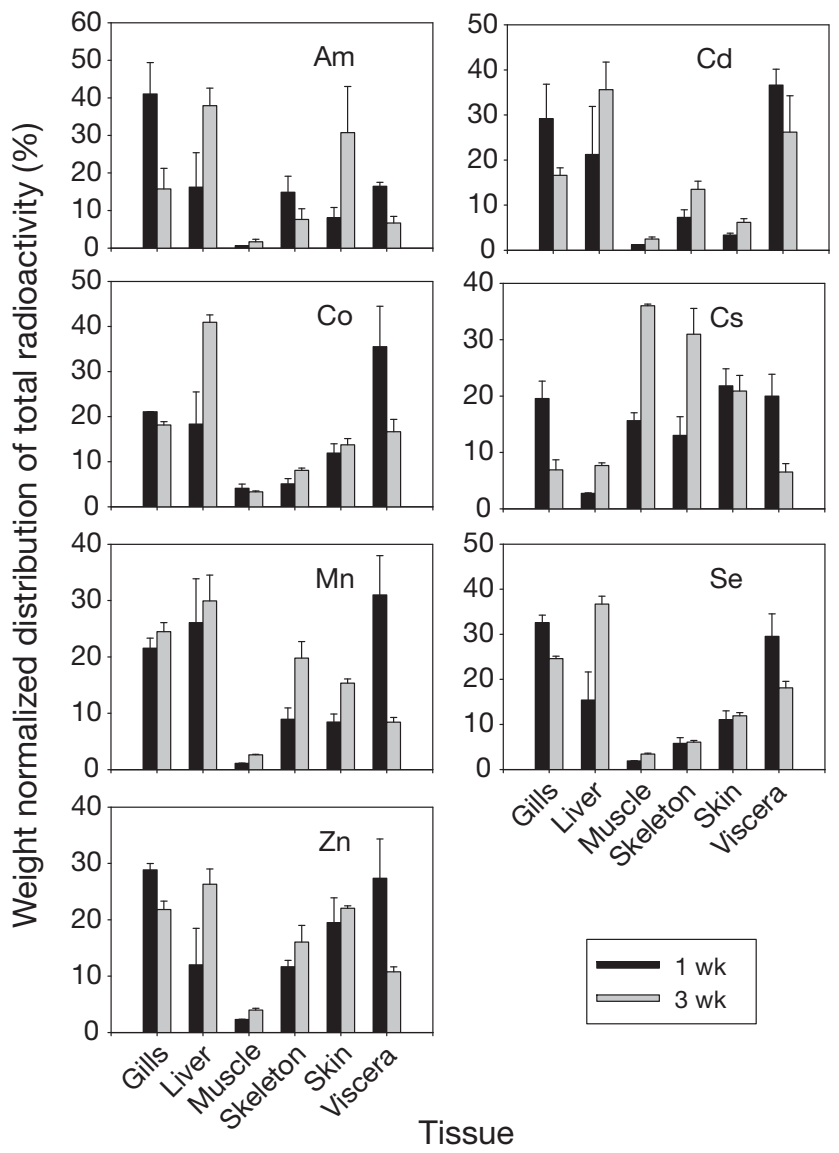

Fig. 8. Dicentrarchus labrax. Relative enrichment (weight normalized) in different tissues after 1 and 3 wk of depuration. Means $+\mathrm{SD}, \mathrm{n}=6$ 
et al. (2001) hypothesized that the low algal VCFs for Cs preclude a phytoplankton influence on the build-up of this metal in marine food chains. However, as seen from the trophic transfer data (Figs. 2,4,6), the AE of Cs at all subsequent steps of the food chain is very high and efflux rate constants are low, so the small amount of Cs entering the food chain in phytoplankton cells could affect its build-up in marine food chains, even if considerable accumulation of $\mathrm{Cs}$ occurs through aqueous uptake.

Previous work suggests that upper trophic level (piscivorous) marine fish derive a large proportion of their total body metal burden through dietary exposure (T. Mathews \& N. Fisher unpubl. data, Zhao et al. 2001). Our Cs TTF values agree with previous findings for piscivorous marine fish and were consistently the highest of all metals studied (Figs. 3, 5 \& 7), showing evidence of biomagnification potential at each trophic level (TTFs $\geq 1$ ). In addition, we observed an increase in Cs TTFs with increasing trophic level, approaching 1 at the upper end for Artemia salina nauplii and approaching 3 for the piscivorous fish Dicentrarchus labrax (Figs. 3, $5 \&$ 7). Cs was also the only metal for which the relative fraction in $D$. labrax muscle tissue increased significantly from 1 to $3 \mathrm{wk}$ of depuration (Fig. 8). While this does not mean that the total concentration of Cs in muscle tissue of D. labrax is increasing during the depuration period, it signifies either that Cs is mobilized from other tissues into muscle over time or that $\mathrm{Cs}$ is lost more rapidly from tissues other than muscle. Mercury, particularly in the methylated form, is the only other metal that is widely recognized to biomagnify in aquatic food chains, and it occurs largely in the muscle tissue of both planktivorous and piscivorous fish (Pickhardt et al. 2006, Mathews \& Fisher 2008).

Because particle-reactive Am remains bound to algal cell surfaces, its assimilation in herbivores is very low and its potential for transfer up the food chain is similarly low. The low AE that we report for Am in Artemia nauplii feeding on Isochrysis galbana is similar to previously reported values in copepods feeding on diverse phytoplankters (Wang et al. 1996b), and it is the low AE from phytoplankton to zooplankton that limits the build-up of Am in marine food chains. The $\mathrm{AE}$ values of Am at each trophic level studied were sufficiently low and the corresponding efflux rate constants sufficiently high that the TTFs of Am at each trophic level were the lowest of all metals considered and decreased with increasing trophic level (Figs. 3, 5 \& 7). In Dicentrarchus labrax, the relative fraction of Am (and other metals studied) in the liver increased from 1 to $3 \mathrm{wk}$ of depuration, but unlike any other metal, the relative fraction of Am in the skin of D. labrax also significantly increased (Fig. 8).
The chemistry of Se in aquatic systems is complex, as it exists in numerous oxidation states in nature. In seawater, selenium exists largely in the inorganic forms selenate (VI) and selenite (IV), as well as in organic selenides (Cutter \& Bruland 1984). Among the inorganic species of Se, selenite is actively accumulated by phytoplankton (Fisher \& Wente 1993, Baines \& Fisher 2001), which is consistent with the high VCFs in Isochrysis galbana exposed to selenite in our experiments (Table 1). Once inside phytoplankton cells, Se is reduced and covalently incorporated into selenoamino acids (Wrench 1978, Bottino et al. 1984), which are readily assimilated by bivalves and other herbivores (Wang \& Fisher 1999a). Previous work demonstrated that bivalves and other aquatic invertebrates accumulate little Se from the dissolved phase and that $>90 \%$ of Se in these organisms is derived from dietary exposure (Wang \& Fisher 1999b).

The AEs of Se that we observed were only slightly lower than those of $\mathrm{Cs}$, and the $\mathrm{k}_{\mathrm{e}} \mathrm{s}$ were slightly higher at each trophic level. TTF values for Se approached unity for all trophic levels at the higher IRs and at the high AEs considered (Figs. 3, 5 \& 7). Figs. 4 \& 6 reveal that most metals showed a rapid initial loss from both Sparus auratus and Dicentrarchus labrax (corresponding to defecation by the fish), and then a slower loss corresponding to physiological turnover of the metal; in contrast, neither Cs nor Se showed this rapid evacuation, suggesting that these metals were quickly absorbed in the gut and loss was through means other than defecation. This pattern was not seen in Artemia nauplii (Fig. 2).

The remaining 4 metals $(\mathrm{Cd}, \mathrm{Co}, \mathrm{Mn}$, and $\mathrm{Zn})$ behaved somewhat similarly to one another in the simplified food chain studied here, with Mn displaying the lowest AE and TTF values of the 4. It would appear that neither Mn nor Co are likely to biomagnify in marine food chains. $\mathrm{Zn}$ and $\mathrm{Cd}$, perhaps because of their affinity for sulfur ligands and proteinaceous tissues (Nieboer \& Richardson 1980), have the potential to biomagnify in certain organisms (Wang 2002, Croteau et al. 2005). Like Cs and Se, Zn had TTFs that increased with increasing trophic level and exceeded 1 at the higher IRs and AEs considered for sea bass in this study (Fig. 7). Although TTF values $>1$ generally indicate the potential for biomagnification, $\mathrm{Zn}$ is not generally expected to biomagnify in piscivorous fish because, as in many other marine organisms, Zn concentrations in fish are regulated (Goodyear \& Boyd 1972, Roch et al. 1982). Zn AEs in marine animals vary with $\mathrm{Zn}$ concentration in the diet (Wang et al. 1996a) such that Zn tissue concentrations remain fairly constant among fish with increasing trophic level and with increasing fish size (Amiard et al. 1987, Kjoss et al. 2006). However, several studies have reported ele- 
vated $\mathrm{Zn}$ concentrations in fish, and there is evidence of $\mathrm{Zn}$ biomagnification in some food chains both in the laboratory and in the field (Zhang \& Wang 2007). Thus, the high TTF values that we report for Dicentrarchus labrax could be evidence of $\mathrm{Zn}$ biomagnification, since the Zn content in its prey Sparus auratus is low, indicating high assimilation efficiency in D. labrax.

In studying biomagnification of any contaminant in aquatic food webs, it is important to consider that metals may be concentrated or sequestered in different tissues of animals, sometimes for detoxification purposes (e.g. liver). Field studies examining metal bioaccumulation in fish often report muscle tissue concentrations (principally for public health reasons) and compare metal concentrations in fish muscle tissue from different trophic levels for the assessment of metal biomagnification. In the present study, we compared metal levels in whole organisms, something that is feasible using the radioisotope approach employed. In this way, we were able to obtain an integrative assessment (taking all tissues into account) of whether or not biomagnification occurs between 2 trophic levels.

The tissue data shown in Fig. 8 show that the relative pools of all metals significantly increased over time in the liver of Dicentrarchus labrax. As mentioned above for the relative increase of Cs in the muscle tissue of $D$. labrax, this does not necessarily show that total metal concentrations increased in the liver, but rather that metals were either mobilized from other tissues into the liver over time, or that they were lost more rapidly from tissues other than the liver. Metals stored in granules of invertebrates are often bound to metallothioneins or other compounds that complex metals, and this affects the assimilability of metals in predators (Seebaugh \& Wallace 2004). Different tissues in fish have different metal turnover rates (Mathews et al. 2008), which affects the overall turnover time for metals in fish and may affect the bioavailability of metals to predators of these fish. Future studies should examine the effects of metal bioavailability from different fish tissues in predators.

Overall, we showed that, in a food chain exposed to environmentally realistic metal concentrations through the consumption of whole prey organisms, the only metal that consistently showed potential for biomagnification at all trophic levels considered was $\mathrm{Cs}$, which is likely attributable to the high AEs and low $\mathrm{k}_{\mathrm{e}} \mathrm{s}$ of this metal at each trophic step. Se had high AEs but also relatively high $\mathrm{k}_{\mathrm{e}} \mathrm{s}$, which is why TTFs were not consistently $>1$. Zn also had high TTFs, but this was due to low $\mathrm{k}_{\mathrm{e}} \mathrm{s}$ rather than high AEs. Because efflux of metals from animals results from simultaneous loss from different tissues, each with a specific turnover rate, $\mathrm{k}_{\mathrm{e}}$ values measured in experiments such as those described here, while applicable to modeling the retention of metals in whole animals, are often not well understood. Future experiments that systematically address the efflux rates from individual organs or biochemical compartments may help to understand how overall $\mathrm{k}_{\mathrm{e}} \mathrm{s}$ respond to environmental variables.

Acknowledgements. This research was supported by grants from the NSF (CHE0221934) and SERDP (W912HQ06C0014). We thank J. Teyssié, F. Oberhansli, and R. Jeffree for laboratory assistance and many helpful suggestions, and 3 anonymous reviewers for thoughtful comments on the manuscript.

\section{LITERATURE CITED}

Adam C, Garnier-Laplace J (2003) Bioaccumulation of silver$110 \mathrm{~m}$, cobalt- 60 , cesium-137, and manganese- 54 by the freshwater algae Scenedesmus obliquus and Cyclotella meneghiana and by suspended matter collected during a summer bloom event. Limnol Oceanogr 48:2303-2313

Amiard JC, Amiard-Triquet C, Berthet B, Metayer C (1987) Comparative study of the patterns of bioaccumulation of essential $(\mathrm{Cu}, \mathrm{Zn})$ and non-essential $(\mathrm{Cd}, \mathrm{Pb})$ trace metals in various estuarine and coastal organisms. J Exp Mar Biol Ecol 106:73-89

Baines SB, Fisher NS (2001) Interspecific differences in the bioconcentration of selenite by phytoplankton and their ecological implications. Mar Ecol Prog Ser 213:1-12

Baines SB, Fisher NS, Stewart R (2002) Assimilation and retention of selenium and other trace elements from crustacean food by juvenile striped bass (Morone saxatilis). Limnol Oceanogr 47:646-655

Baines SB, Fisher NS, Kinney EL (2005) Influence of temperature on dietary metal uptake in Arctic and temperate mussels. Mar Ecol Prog Ser 289:201-213

> Bottino NR, Banks CH, Irgolic KJ, Micks P, Wheeler AE, Zingaro RA (1984) Selenium containing amino acids and proteins in marine algae. Phytochemistry 23:2445-2452

Croteau MN, Luoma SN, Stewart AR (2005) Trophic transfer of metals along freshwater food webs: evidence of cadmium biomagnification in nature. Limnol Oceanogr 50: 1511-1519

Cutter GA, Bruland KW (1984) The marine biogeochemistry of selenium: a re-evaluation. Limnol Oceanogr 29: 1179-1192

Fisher NS, Reinfelder JR (1995) The trophic transfer of metals in marine systems. In: Tessier A, Turner DR (eds) Metal speciation and bioavailability in aquatic systems. Wiley, New York, p 363-406

Fisher NS, Wente M (1993) The release of trace elements by dying marine phytoplankton. Deep-Sea Res I 40:671-694

Fisher NS, Bjerregaard P, Fowler SW (1983) Interactions of marine plankton with transuranic elements.1. Biokinetics of neptunium, plutonium, americium, and californium in phytoplankton. Limnol Oceanogr 28:432-447

Fisher NS, Teyssie JL, Fowler SW, Wang WX (1996) Accumulation and retention of metals in mussels from food and water: a comparison under field and laboratory conditions. Environ Sci Technol 30:3232-3242

Garnier-Laplace J, Adam C, Baudin J (2000) Experimental kinetic rates of food-chain and waterborne radionuclide transfer to freshwater fish: a basis for the construction of fish contamination charts. Arch Environ Contam Toxicol 39:133-144

Goodyear CP, Boyd CE (1972) Elemental composition of 
largemouth bass (Micropterus salmoides). Trans Am Fish Soc 101:545-547

Guillard RR, Ryther JH (1962) Studies of marine planktonic diatoms I. Cyclotella nana Hustedt, and Detonula confervacea (Cleve) Gran. Can J Microbiol 8:229-239

Heldal HE, Stupakoff I, Fisher NS (2001) Bioaccumulation of ${ }^{137} \mathrm{Cs}$ and ${ }^{57} \mathrm{Co}$ by five marine phytoplankton species. J Environ Radioact 57:231-236

Hook SE, Fisher NS (2001) Reproductive toxicity of metals in calanoid copepods. Mar Biol 138:1131-1140

IAEA (International Atomic Energy Agency) (2004) Sediment distribution coefficients and concentration factors for biota in the marine environment. IAEA, Vienna

Kjoss VA, Wood CM, McDonald DG (2006) Effects of different ligands on the bioaccumulation and subsequent depuration of dietary $\mathrm{Cu}$ and $\mathrm{Zn}$ in juvenile rainbow trout (Oncorhynchus mykiss). Can J Fish Aquat Sci 63:412-422

Luoma SN, Rainbow PS (2005) Why is metal bioaccumulation so variable? Biodynamics as a unifying concept. Environ Sci Technol 39:1921-1931

Mathews T, Fisher NS (2008) Evaluating the trophic transfer of cadmium, polonium, and methylmercury in an estuarine food chain. Environ Toxicol Chem 27:1093-1101

Mathews T, Fisher NS, Jeffree RA, Teyssié JL (2008) Assimilation and retention of metals in teleost and elasmobranch fishes following dietary exposure. Mar Ecol Prog Ser 360:1-12

Meyer JS, Adams WJ, Brix KV, Luoma SN, Mount DR, Stubblefield WA, Wood CM (2005) Toxicity of dietborne metals to aquatic organisms. SETAC Press, Pensacola, FL

Morel FMM, Reinfelder JR, Roberts SB, Chamberlain CP, Lee JG, Yee D (1994) Zinc and carbon co-limitation of marine phytoplankton. Nature 369:740-742

Nieboer E, Richardson DHS (1980) The replacement of the non-descript term heavy metals by a biologically and chemically significant classification of metal ions. Environ Pollut B 1:3-26

Pauly D (1989) Food consumption by tropical and temperate fish populations-some generalizations. J Fish Biol 35: $11-20$

Pickhardt PC, Stepanova M, Fisher NS (2006) Contrasting uptake routes and tissue distributions of inorganic and methylmercury in mosquitofish (Gambusia affinis) and redear sunfish (Lepomis microlophus). Environ Toxicol Chem 25:2132-2142

Reinfelder JR, Fisher NS (1991) The assimilation of elements ingested by marine copepods. Science 251:794-796

Reinfelder JR, Fisher NS (1994) The assimilation of elements

Editorial responsibility: Irina Sokolova,

Charlotte, North Carolina, USA ingested by marine planktonic bivalve larvae. Limnol Oceanogr 39:12-20

Reinfelder JR, Fisher NS, Luoma SN, Nichols JW, Wang WX (1998) Trace element trophic transfer in aquatic organisms: a critique of the kinetic model approach. Sci Total Environ 219:117-135

Roch M, McCarter JA, Matheson AT, Clark MJR, Olafson RW (1982) Hepatic metallothionein in rainbow trout (Salmo gairdneri) as an indication of metal pollution in the Campbell River system. Can J Fish Aquat Sci 39:1596-1601

Schlekat CE, Lee BG, Luoma SN (2002) Dietary metals exposure and toxicity to aquatic organisms: implications for ecological risk assessment. In: Newman MC, Roberts $\mathrm{MH}$, Hale RC (eds) Coastal and estuarine risk assessment. CRC Press, Boca Raton, FL, p 151-188

Seebaugh DR, Wallace WG (2004) Importance of metal-binding proteins in the partitioning of $\mathrm{Cd}$ and $\mathrm{Zn}$ as trophically available metal (solid TAM) in the brine shrimp Artemia franciscana. Mar Ecol Prog Ser 272:215-230

> Wang WX (2002) Interactions of trace metals and different marine food chains. Mar Ecol Prog Ser 243:295-309

Wang WX, Fisher NS (1998) Accumulation of trace elements in a marine copepod. Limnol Oceanogr 43:273-283

Wang WX, Fisher NS (1999a) Assimilation efficiencies of chemical contaminants in aquatic invertebrates: a synthesis. Environ Toxicol Chem 18:2034-2045

> Wang WX, Fisher NS (1999b) Delineating metal accumulation pathways for aquatic invertebrates. Sci Total Environ 237/238:459-472

Wang WX, Ke CH (2002) Dominance of dietary intake of cadmium and zinc by two marine predatory gastropods. Aquat Toxicol 56:153-165

Wang WX, Fisher NS, Luoma SN (1996a) Kinetic determinations of trace element bioaccumulation in the mussel Mytilus edulis. Mar Ecol Prog Ser 140:91-113

Wang WX, Reinfelder JR, Lee BG, Fisher NS (1996b) Assimilation and regeneration of trace elements by marine copepods. Limnol Oceanogr 41:70-81

- Wrench JJ (1978) Selenium metabolism in the marine phytoplankters Tetraselmis tetrathele and Dunaliella minuta. Mar Biol 49:231-236

Zhang L, Wang WX (2007) Size-dependence of the potential for metal biomagnification in early life stages of marine fish. Environ Toxicol Chem 26:787-794

Zhao XG, Wang WX, Yu KN, Lam PKS (2001) Biomagnification of radiocesium in a marine piscivorous fish. Mar Ecol Prog Ser 222:227-237

Submitted: December 30, 2007; Accepted: April 23, 2008

Proofs received from author(s): August 28, 2008 